\title{
A to $\mathrm{Z}$ of Green Marketing in India
}

\author{
Ms Anna Khan \\ Research Scholar \\ Department of Business Administration Aligarh Muslim University.
}

\begin{abstract}
From the time the industrial era started, humans have used nature selfishly. Man has been accused of heartlessly damaging the environment and has been found guilty of ruining the ecology. This has in turn reflected in the major calamities and catastrophe that we face today. The famines and floods or the melting of the glaciers are some of the examples of human carelessness. However it has become the need of the hour to focus on what can be done to tackle the situation at hand and focus on building a sustainable world.

The following paper will try to 1 ) understand the term green marketing 2) focus on whether Indians are a green community 3 ) steps taken by government to ensure environment protection 4) how the Indian companies are responding green issues
\end{abstract}

Keywords Green Marketing, Sustainability, Consumer Behavior, Green Community

\section{INTRODUCTION}

Since the advent of the industrialization man has been severely damaging his natural environment. The urge to save the sinking ecology is not merely a passing fad, but has indeed become the need of the hour. Environment protection must be practiced with urgency. The melting of Himalayan glaciers and the tsunami threat and other natural calamities is pointing towards the increasing alert of global warming. Manmade disasters like the Gulf of Mexico oil spill and the union carbide plant gas leak in India, has raised major questions regarding the safety and validity of human progress.
It can be said that to overcome this challenge lifestyle changes will need to be incorporated into the lives of the people. More so it is the responsibility of the developing countries, like India, to make their way towards development in a sustainable fashion.

But the onus does not lie only on the government but also on the citizens of the country, the buyers and the sellers to make sensible choices and demand sensible goods, which have minimum impact on the environment

\section{GREEN MARKETING}

Green marketing is considered one of the major trends in modern business (Kassaye, 2001; McDaniel and Rylander, 1993; Pujari and Wright, 1996). Soonthonsmai (2007) defined green marketing as the activities taken by firms that are concern about the environment or green problems by delivering the environmentally sound goods or services to create consumers and society's satisfaction. Other definitions of green marketing as proposed by marketing scholars include social marketing, ecological marketing or environmental marketing. Harrison (1993) proposed green marketing strategy by firms through positioning the environmental benefits of green products to consumers' mindset to influence their purchasing decision. Peatitie (1995) and Welford (2000) defined green marketing as the management process responsible for identifying, anticipating and satisfying the requirements of customers and society in a profitable and sustainable way. In reality, companies that pursue green marketing encounter numerous challenges mainly from the variability of demand, un-favorable consumer perception and high cost (Gurau 
and Ranchhod, 2005). The key concern lies in an understanding of green consumers and their characteristics to enable firms to develop a new target and segmentation strategies (D'Souza et al., 2007)

\section{ENVIRONMENTAL ISSUES IN INDIA}

Pollution, Deforestation and Wildlife trade are some of the critical issues that India grapples with every day. As the country's population and economy continue to grow, the need to find solutions becomes more urgent every day. Across India, concern is mounting over an ever growing list of environmental problems.

More people means increased pressure on natural resources (from water to forests), while an economy in high-gear is leaving a trail of pollution that's affecting not only India, but the rest of the world too.

\subsection{Deforestation}

India is witnessing a rising demand for forest-based products. This is causing deforestation and encroachment into forest protected areas, which leads to a severe loss of natural resources.

It is estimated that total industrial round wood consumption in India could exceed 70 million $\mathrm{m}^{3}$ per year by the end of the decade (350,000 large shipping containers), while domestic supply would fall short of this figure by an estimated 14 million $\mathrm{m}^{3}$.

As the nation will have to depend heavily on imports to meet this growing demand, there is fear that this could result in loss of high conservation value forests and biodiversity elsewhere..

\subsection{Air Pollution}

India has the worst air pollution in the entire world, beating China, Pakistan, Nepal and Bangladesh, according to a study released during this year's World Economic Forum in Davos. Of 132 countries whose environments were surveyed, India ranks dead last in the 'Air (effects on human health)' ranking. The annual study, the Environmental Performance Index, is conducted and written by environmental research centers at Yale and Columbia universities with assistance from dozens of outside scientists. The study uses satellite data to measure air pollution concentrations. The World Health Organization estimates that about two million people die prematurely every year as a result of air pollution, while many more suffer from breathing ailments, heart disease, lung infections and even cancer. Fine particles or microscopic dust from coal or wood fires and unfiltered diesel engines are rated as one of the most lethal forms or air pollution caused by industry, transport, household heating, cooking and ageing coal or oil-fired power stations. There are four reasons of air pollution are - emissions from vehicles, thermal power plants, industries and refineries. The problem of indoor air pollution in rural areas and urban slums has increased.

\subsection{River water Pollution}

Contaminated and polluted water now kills more people than all forms of violence including wars, according to a United Nations report released on March 22, 2010 on World Water Day that calls for turning unsanitary wastewater into an environmentally safe economic resource. According to the report - titled "Sick Water?" -- 90 percent of wastewater discharged daily in developing countries is untreated, contributing to the deaths of some 2.2 million people a year from diarrheal diseases caused by unsafe drinking water and poor hygiene. At least 1.8 million children younger than age 5 die every year from water-related diseases.

Fully 80 percent of urban waste in India ends up in the country's rivers, and unchecked urban growth across the country combined with poor government oversight means the problem is only getting worse. A growing number of bodies of water in India are unfit for human use, and in the river Ganga holy to 
the country's 82 percent Hindu majority, is dying slowly due to unchecked pollution.

\subsection{Groundwater exploitation}

Groundwater exploitation is a serious matter of concern today and legislations and policy measures taken till date, by the state governments (water is a state subject) have not had the desired effect on the situation.

According to the World Health Organization on World Water Day 2011, on March 22, 2011 each year, an estimated four billion people get sick with diarrhea as a result of drinking unsafe water, inadequate sanitation, and poor hygiene. Nearly two million people die from diarrhea each year, and many of them children under the age of five, poor, and living in the developing world. Improper disposal of solid waste, both by the public and Bruhat Bangalore Mahanagara Palike (BBMP) is causing direct contamination of groundwater, according to Dr M A Farooqui, scientist, Central Ground Water Board (CGWB) on May 26, 2011.

\subsection{Greenhouse Gas Emissions}

India emits the fifth most carbon of any country in the world. At 253 million metric tons, only the U.S., China, Russia, and Japan surpassed its level of carbon emissions in 1998. Carbon emissions have grown ninefold over the past forty years. In this Industrial Age, with the ever-expanding consumption of hydrocarbon fuels and the resultant increase in carbon dioxide emissions, that greenhouse gas concentrations have reached levels causing climate change. Going forward, carbon emissions are forecast to grow $3.2 \%$ per annum until 2020.

According to the UN Framework Convention on Climate Change and the Kyoto Protocol, the most industrialized countries are mainly responsible for causing climate change. Thus equity requires that they should sharply reduce their emissions in order to arrest further climate change and allow other countries access to their fair share of atmospheric resources in order to develop.

\section{STEPS TAKEN BY GOVERNMENT}

\subsection{Projects to save Agra monuments back on track}

The growing threat from pollution to India's prized monuments, including the Taj Mahal, has prompted the authorities to speed up action on March 22, 2011. The project aims to insulate the world heritage monuments, including Fatehpur Sikri, Agra Fort and the Taj Mahal. A set of eight schemes to control pollution and save these monuments has been submitted for clearance from the state government before being presented to the Planning Commission to include them in the 12th Five Year Plan (2012-2017).

\subsection{World Bank Cooperation on India's Green Agenda}

India and the World Bank agreed on January 13, 2011 to further strengthen their partnership to advance India's green-growth agenda. The Bank will now support to strengthen Indian capacity of Central Pollution Controls Board, State Pollution Control Boards and biodiversity conservation in addition to other various projects for which financial support have already been given.

\subsection{India to build advanced coal-fired power plant}

Indian scientists aim to built an advanced ultra-super critical coal-fired power plant in the next six years. Once realised, the plant is expected to put India in a very select group of nations having the technology which would reduce the amount of pollution when compared with the current thermal power plants.

\subsection{Green Court launched}

India launched a "green" court on October 19,2010 to make polluters pay damages as it steps up its policing of the country's environmental laws. The then, Environment Minister Jairam Ramesh said India was only the third country in the world after Australia 
and New Zealand to set up such a tribunal. "This is the first body of its kind (in India) to apply the polluter pays principle and the principle of sustainable development," Ramesh told reporters in New Delhi.

\subsection{National Action Plan on Climate Change}

The Centre has made a provision of Rs. 25,000 crore to mitigate the effects of climate change, a serious problem that India will face in the coming decades, Minister of State for Environment and Forests Jairam Ramesh told the Rajya Sabha on August 21, 2010. Besides, the Finance Ministry has also sanctioned Rs. 5,000 crore as recommended by the 13th Finance Commission to tackle this serious problem," Mr. Ramesh said About 220 scientists from 120 research institutions were working on assessing the impact of climate change on agriculture, water, health and forests.

\subsection{Steps in Budget 2010-11 for the Environment}

The increased pollution levels associated with industrialisation and urbanisation, a number of proactive steps have been proposed in the Union Budget 2011. One of the major steps include:

National Clean Energy Fund (NCEF) - for funding research and innovative projects in clean energy technology. Allocation for National Ganga River Basin Authority has been doubled in 2010-11 to Rs.500 crore. The "Mission Clean Ganga 2020" under the National Ganga River Basin Authority (NGRBA) with the objective that no untreated municipal sewage or industrial influent will be discharged into the National river has already been initiated.

\section{HOW GREEN IS THE INDIAN CITIZEN}

The Greendex survey report, (excerpts from the greendex survey have been quoted)

National Geographic conducted its inaugural Greendex survey in January 2008. That first
Greendex survey of 14 countries around the world ranked average consumers in those countries according to the environmental sustainability of their behavior. Consumers in the large developing economies of Brazil, India and China scored highest, while Canadians and Americans, with their relatively massive environmental footprints as individuals, scored lowest.

The top-scoring consumers of 2010 are in the developing economies of India, Brazil, China. Consumers registering the largest 2010 vs 2008 increase in environmentally sustainable consumer behavior were the Indians, Russians and Americans. Environmentally sustainable behavior among average consumers in India, China, Mexico, Russia, Hungary, Japan, Great Britain, and Canada has also increased steadily each year.

Despite Indian consumers' lifestyles continuing to emerge as the most environmentally sustainable of any of the countries surveyed according to the Greendex, Indians were also the most likely to cite the perception that the seriousness of environmental problems is exaggerated as a barrier to action. In all other countries surveyed, fewer than one-quarter said that they are discouraged from taking action because they think that environmental problems are exaggerated, while 40 percent of Indians said they feel this way. In the longer term, these perceptions may act as a brake on a long-term adoption of sustainable lifestyles in India as the subcontinent's economy continues to develop.

Overall Greendex scores have increased in India, China and Russia as a result of changes in a number of the indicators that make up the Greendex.

Regarding housing, Brazilians, Indians, Mexicans, and Chinese top the housing subindex. There is also a growing trend to conserve fresh water, particularly among Indian and Russian consumers. Only Indians and South Koreans are more likely to report that their consumption of fuel has increased than to say that their consumption has decreased. 
In case of transportation, the possession of cars or trucks is much more common among consumers in industrialized economies than emerging economies. Consumers in China, India, and Argentina are the least likely to own at least one, but the use of cars is increasing at least in China and India. Still, Chinese and Indian consumers are the most likely to say that they live close to their usual destinations to minimize the impact of their personal transportation on the environment, and Indians and Chinese retain the first and second ranks on the sub-index respectively. Chinese and Indian consumers are the most frequent users of public transportation and the most likely to report that they use it to save fuel and reduce pollution at least in part. Regarding food, Russians, Australians, Hungarians, Chinese, and Indians consume food they have grown on their own more frequently than those in other countries, which contributes positively to their Greendex score.

In case of goods, since 2008, the number of consumers who prefer to repair rather than replace broken items has continued to increase in China, India, and Russia.

Consumers in most countries say that environmentally friendly product premiums are generally worth it to them, but Russians, Indians, and Brazilians have the opposite opinion. Actions such as avoiding environmentally unfriendly products or buying environmentally friendly products are most common in emerging economies, particularly among Chinese and Indian consumers.

Indians and Chinese are the only two countries in which a majority of consumers report avoiding excessively packaged goods. This tendency has increased from 2008 levels.

In short it can be said that Indians are a green community and prefer greener alternatives over non green ones. It can therefore be predicted that India is making its way forward towards a sustainable development.

\section{HOW IS THE INDIAN CORPORATE RESPONDING?}

HCL has launched its range of eco-friendly notebooks, HCL ME 40. HCL claims that this was India's first PVC free and ecofriendly notebook. This notebook is completely free from polyvinyl chloride (PVC) material and other harmful chemicals. Further, Bureau of Energy Efficiency has given HCL eco-friendly products a five-star rating, and they also meet REACH (REACH is the European Community Regulation on chemicals and their safe use) standards and are 100 per cent recyclable and toxin free.

In 2007, Voltas initiated the 'Green' range of air-conditioners, following which the government made it mandatory for home appliances to have energy star ratings.

Energy Star is an international standard for energy efficient consumer products that originated in the US.

Thus, devices carrying the star logo, such as computer products and peripherals, kitchen appliances and other products, use about 2030 per cent less energy than the set standards. The other company to launch wide range of eco-friendly desktops is Wipro. Introduced under the Wipro Green Ware initiative, these products aim to cut down e-waste in environment.

Here, the systems launched are toxin free and operate under a total recycling policy. With the removal of the toxins, recycling of the electronic products would be safer, say company executives.

Wipro has 17 e-waste collection centers in India where products are collected and recycled. Also, 12 Wipro campuses in the country have been certified as green buildings.

Next in the line to join the eco-friendly product wagon is the Indian tyre manufacturer MRF with its ZSLK series. The premium eco-friendly tubeless tyres MRF ZSLK are made from unique silicabased rubber compounds and promises to 
offer fuel efficiency for vehicle owners. The tyres had been tested extensively on Indian road conditions with emphasis on endurance, wet and dry braking, the company said in a statement.

At present, the ZSLK series are available for models including Honda City/Civic, Ford Fiesta, Hyundai Santro, Maruti SX4, Wagon $\mathrm{R}$, Skoda Octavia, Tata Indica, Nissan Micra. India-based cement manufacturer $\mathbf{A C C}$ has recently launched its eco-friendly brand, 'Concrete+'. This brand uses fly ash (a hazardous industrial waste) to help conserve natural resources, thus making it an ecofriendly product. The new product has been designed exclusively to ensure high durability and resistance of structures under extreme climate.

Fevicol, a leading brand of adhesive in India, has introduced environment friendly synthetic resin adhesive. Claiming to be India's first eco-friendly adhesive, Fevicol AC Duct King Eco Fresh, boasts of being an all-in-one adhesive.

The company says that this water-based adhesive has exceptional bonding strength and spreads smoothly at room temperature without emitting any toxic fumes. It is an ideal adhesive for AC Duct insulation for all residential and industrial projects.

Eco-friendly line of clothing is fast growing fashion trend. Though it had a slow take off, it now has many takers. Anita Dongre has now joined the line of eco-fashion with her brand, Grassroot. "My eco-friendly brand Grassroot is a 100 per cent environmentfriendly brand. We use certified eco-friendly $\&$ organic fabrics; we have partnered with number of NGOs who are engaged into providing and promoting the work of local artisans," says Anita Dongre. For the uninitiated, eco-fashion is a process of creating garments with environment friendly techniques and processes which are nonhazardous to the environment. Largely, ecoclothing uses organic cotton, bamboo jersey, viscose and linen, etc. Earth friendliness is the hallmark of the Vivanta line, just as it is at all Taj hotels. The parent company follows guidelines established at a United Nations Earth Summit and endorsed by nearly 200 countries. These green benchmarks are monitored by a leading worldwide certifier, Green Globe. Taj aims to bring the total of its Vivanta hotels to 30-plus in the next 2 years, totaling 5,000-plus guest rooms. So, from LCDs to clothing, every brand is giving you an opportunity to ride the green wave. Go ahead, make a choice and join the green revolution.

\section{CONCLUSION}

In conclusion, it can be said that India grapples with scores of environmental problems, which can said to be critical in their own right. The issues like air pollution, water pollution and deforestation need to be met with utmost gravity and urgency. Water and air are the two basic components which are required to sustain life. The contamination of which can lead to serious outcomes. Water pollution can lead to some life threatening consequences, an increased amount of chlorinated solvents in water may result in liver damage and even cancer, chemicals like DDT in water may cause neurological problems and certain chemicals can even cause reproductive and endocrine damage. While on the other hand air pollution cause diseases like respiratory problems, complications in cystic fibrosis and cardiovascular diseases. Cutting down of trees aggravates the problem of air pollution, by causing an increase in carbon dioxide levels and increased green house effect.

While the picture in terms of environment looks grim, a silver lining comes in the fact that the Indians have come to realize the importance of environmental concern and are ready to mould themselves to suit the environment and not vice versa. The government has taken positive steps in insuring the environment stays protected. But the steps taken by the corporate deserves a special mention. Right from software to chemicals, from clothing to hospitality, it seems that the Indian industries are ready to 
actively save their ecology as India moves towards development. This can said be a green marketing phenomenon that the Indian business community seems to have enthusiastically inculcated in their businesses. This positive step is the much needed action as the nation prepares to become a sustainable and environmentally positive economy.

\section{REFERENCES}

1. D’Souza, C., Taghian, M. Lamb, P. and Peritiatko. R (2007). Green decisions: Demographics and consumer understanding of environmental labels. International Journal of Consumer Studies, 31, 371-376.

2. Gurau, C. and Ranchhod, A. (2005). "International green marketing : A comparative study of British and Romanian firms." Inernational Marketing Review, 22(5), 547-561.

3. Harrison, E.B (1993). "Going green: How to communicate your company's environmental commitment." Homewood, IL: Richard, D. Irwin, Inc.

4. Kassaye, Wossen. W (2001)" green Dilema", Marketing Intelligence \& planning,Vol. 19 Iss:6,pp.444-455

5. Mc Daniel, Stephen. W and Raylander, David .H, (1993) "Strategic Green Marketing", Journal of Consumer Marketing. Vol. 10 Iss: 3,pp.4-10

6. Peattie,K. (1995). Environmental Marketing Management, London : Pitman Publishing
7. Pujari, Devashish and Wright, Gillian (1996) “ Developing environmentally conscious products strategies : a qualitative study of selected companies in Germany and Britain", Marketing Intelligence \& Planning, Vol.14 Iss:1,pp 19-28.

8. Soonthosmai, V. (2001). Predicting intention and behavior to purchase environmentally sound or green products among Thai consumers: An application of Theory of Reasoned Action, Doctor of Philosophy, Nova Southeastern University.

9. Welford, J.F (1996). Green Marketing Management : A Global Prespective . Cambridge, Mass: Blackwell Publishers Inc.

10. (9)Ministry of Environment. \& forest http://moef.nic.in/index.php

11. (10) United Nations Environment Programme http://www.unepwcmc.org/

12. (11) Ministry of Environment. \& forest http://moef.nic.in/index.php

13. (12) United Nations Environment Programme http://www.unepwemc.org/

14. (13) Asian Brown cloud

15. (14) Pollution and Society http://www.umich.edu/ gs265/soci ety/pollution.htm(15)Carbon dioxide Charts http://rainforests.mongabay.com/09 -carbon_emissions.htm 